\title{
Nepal Earthquake 25 April 2015: Hydro projects damaged, risks and lessons learned for design considerations
}

\author{
Subas Chandra Sunuwar \\ Kathmandu, Nepal \\ Email:sunuwarsc@gmail.com
}

\begin{abstract}
The 25 April 2015 Nepal earthquake of magnitude 7.8 epicentre at Gorkha and magnitude 7.3 aftershocks on 12 May epicentre at Dolakha had devastating impacts on 14 districts including Kathmandu, capital city of Nepal. Death toll was nearly 9,000 and hundreds of thousands of inhabitants became homeless. The earthquake severely damaged mainly surface structures of hydro projects, access roads, clay mortar stone masonry houses and structurally weak concrete houses. Landslides, rock falls, debris flow, liquefaction, river damming, Landslides Dammed Outburst Flood (LDOF) and Glacial Lake Outburst Flood (GLOF) are expected earthquake-induced hazards. However, landslides and grounds shaking were responsible for major damaged. A total of 15 hydro projects in operations and under construction were affected by the earthquake. In hydro projects damages were recorded in surface structures such as power house, settling basin, penstock pipes, and diversion weir constructed at base of steep terrains. For instance, surface penstock pipe, lying at base of rock cliff, of running $40 \mathrm{MW}$ Upper Bhote Koshi Project was ruptured by rock falls and as a result flooded surface powerhouse located downstream by water from penstock and headrace tunnel. Similarly, diversion weir, surface settling basin and headrace penstock pipe of running 5 MW Mialung Project were also severely damaged by slides and rock falls. On the other hand, only minor cracking of sprayed concrete at corners and protruded edges in underground structures were observed. In hydro projects, there is a practice of considering seismic load in design of structures but the effects of earthquake induced hazards were not foreseen. This devastating earthquake gave good lessons for design considerations of hydro projects in future. This article summarises earthquake damage, risks and lessons learned for Hydro projects in Nepal.
\end{abstract}

Keywords: Earthquake, Ground shaking, Rock falls, Landslides

Paper Received: 30 Dec 2018

Paper Accepted: 12 March 2018

\section{INTRODUCTION}

The 25 April 2015 Nepal earthquake Mw 7.8 epicentre at Gorkha and Mw 7.3 aftershocks on 12 May epicentre at Dolakha had devastating impact on 14 districts including Kathmandu, Capital of Nepal. Death toll was nearly 9,000 and hundreds of thousands of inhabitants became homeless. This earthquake severely damaged clay mortar stone masonry houses, structurally weak concrete houses, access roads and surface structures of hydro projects. Damages were responsible for ground shaking and the earthquake induced landslides and rock falls.

In hydro projects, severe damages were recorded in surface structures like power house, penstock pipes, settling basin and diversion weir constructed at base of steep slope and along steep terrains. On the other hand, only minor cracking of sprayed concrete at corner and edges in underground structures was observed. Consequences would be worse if ground was fully saturated during the earthquake event. In hydro projects, there is practice of considering seismic load in design of structures but could not foresee effect of earthquake induced hazards. This devastating earthquake gave good lessons in design considerations of hydro structures. This paper presents earthquake damage, risks and lesson learned for design considerations for hydro projects.

\section{OVERVIEW ON EARTHQUAKE AND EARTHQUAKE-INDUCED HAZARDS AND RISKS}

\section{Gorkha Earthquake characteristics and ground motion}

Main shock Mw 7.8 at Gorkha was migrated about 130 $\mathrm{km}$ to east, Dolakha suggested by distribution of aftershocks including Dolakha aftershocks Mw 7.3 (GEER, 2015). Most of earthquakes are shallow depth of 10 to $15 \mathrm{~km}$. Earthquakes were generated by slip along shallow angle thrust faulting along the Main Himalayan Thrust (MHT). The MHT has a flat-rampflat geometry, where lower flat is creeping, upper flat is locked and the ramp itself is transitional zone (GEER, 2015). The general dip of MHT is very shallow typically less than $10^{\circ}$ (Ader et. al., 2012) with the flat dipping approximately $5^{\circ}$ to $6^{\circ}$ (Fig.1). This recent Gorkha Earthquake is large blind earthquake that ruptured from top of the ramp toward the Main Frontal Thrust (MFT) but did not rupture at surface (GEER, 2015). The Main shock slip was directed towards east from the hypocenter with peak slip about $3 \mathrm{~m}$ (USGS, 2015).

The recorded ground motion in Kantipath, Kathmandu station (placed in soil) is very low Peak Ground Acceleration $(\mathrm{PGA})=0.16 \mathrm{~g}$ and very long period $(5 \mathrm{~S})$ predominant pulse (GEER, 2015). Similarly, PGA recorded in Seismological Centre (placed in soil), Department of Mines and Geology, Lazimpat, 


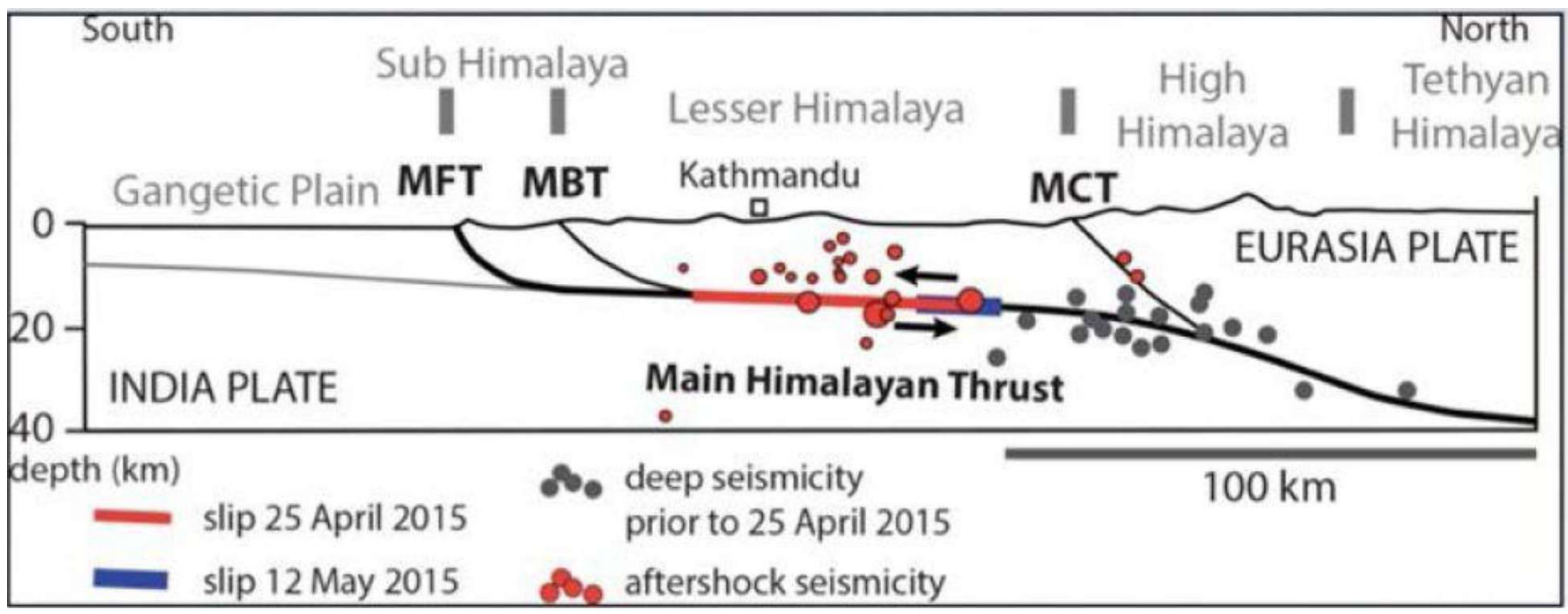

Fig. 1: Generalised cross-section through the Central Nepal Himalaya showing the MHT and model slip of the Gorkha Earthquake 2015 prepared by USGS (2015)

Kathmandu are PGA $=0.15 \mathrm{~g}$ for the geometrical mean of the two horizontal components of main shock with a large PGA of $0.21 \mathrm{~g}$ on the vertical component (Bhattarai et al., 2015). PGA recorded in stations at Kirtipur Municipality, Kathmandu (placed in rock), Tribhuvan University, Kirtipur, Kathmandu (placed in soil), Pulchowk Engineering College, Kathmandu (placed in soil) and Sanothimi, Bhaktapur (placed in soil) are $0.25 \mathrm{~g}$ (E$\mathrm{W}$ direction), $0.21 \mathrm{~g}, 0.15 \mathrm{~g}$ and $0.15 \mathrm{~g}$, respectively (Takai et al., 2016). The USGS preliminary estimation of PGA in Epicentre Gorkha area was $0.35 \mathrm{~g}$ and $0.1-0.15 \mathrm{~g}$ in the Kathmandu valley estimated by Aydan and Ulusay (2015).

More effects of strong ground shaking were observed in narrow ridges, loose soil and jointed/weathered rock on top of steep slope, loose thick soil in steep terrains, old landslides, at base of rock cliff and in loose and saturated soil. For instance, the Tatopani Bazaar near China boarder, situated at the base of steep rock cliff with loose alluvial deposit on top, was badly damaged by slides and rock falls (Fig. 2). Likewise, diversion weir, settling basin and penstock pipe of the Mailung Hydropower Project in Rasuwa, located at the base of steep rock cliff were severely damaged by rock falls and slides (Fig. 2).

\section{Earthquake-induced hazards and risks}

Hydropower structures are either built in or are founded on geologically sensitive materials such as rock and soil. In addition, surface structures are built on the base of hills and steep slopes. Normally surface structures are found more risky than underground structures in the event of earthquake.

Landslides, rock falls, debris flow, liquefaction, river damming, Landslides Dammed Outburst Flood (LDOF) and Glacial Lake Outburst Flood (GLOF) are potential earthquakeinduced hazards. Landslides including rock falls were common in a hilly terrain whereas landslides river damming were
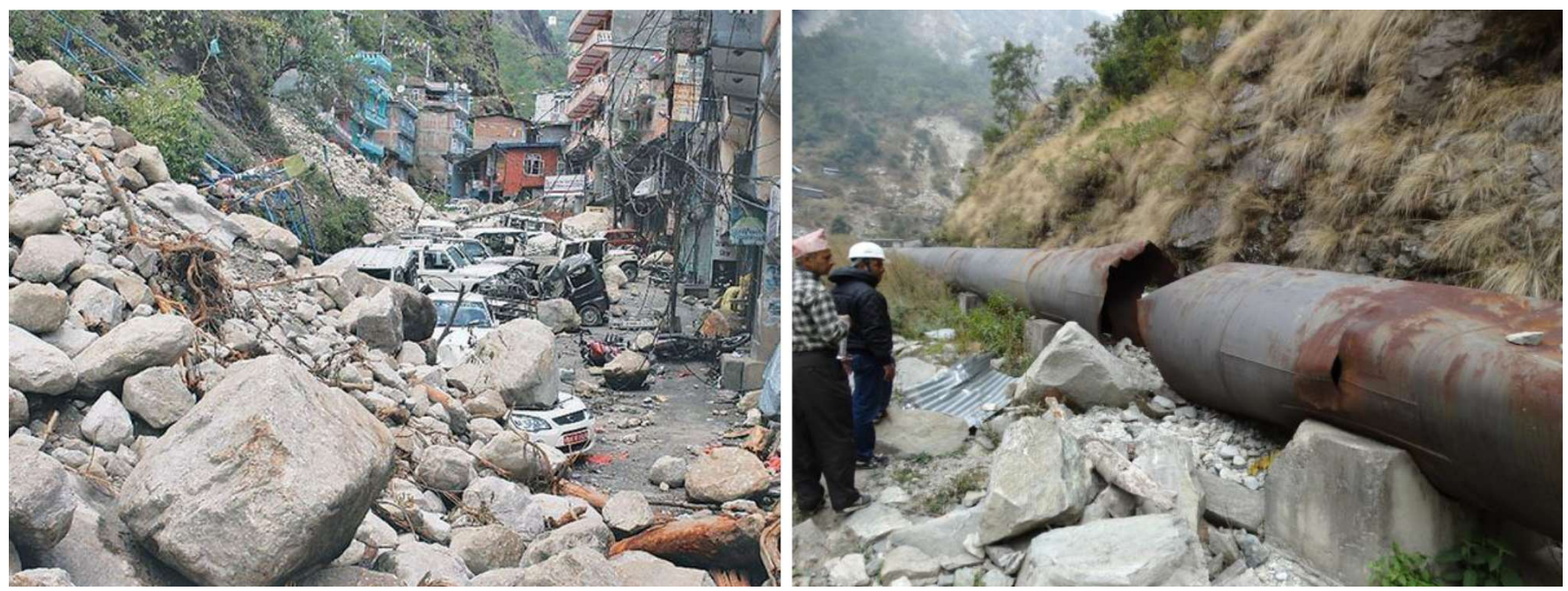

Fig. 2: Severely damaged Tatopani village (Photo: Kantipur) and ruptured penstock pipe by landslides and rock falls of the Mailung project 

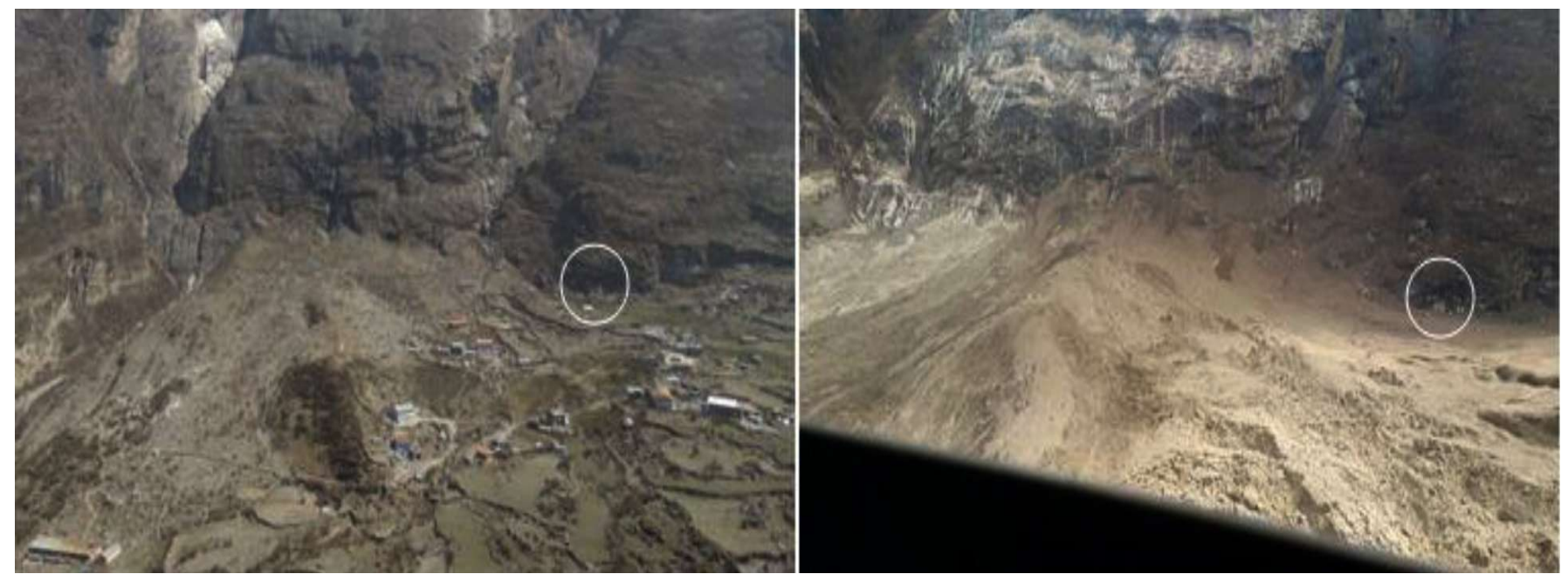

Fig. 3: Langtang village before earthquake and after earthquake (photo: Kantipur)

concentrated in the Marsyandi, the Budhigandaki, and the Trishuli River valleys. In addition, long and deep tension cracks were normally developed in thick soil deposits at edge of steep slopes, ridges and old landslides which are high risk of triggering landslides during rainy season.

The earthquake-induced geohazards pose risk to structures are summarised below:

\section{Landslides}

Landslides triggered by the earthquake due to strong shaking normally observed in steep terrain. Soil slides were prone in thick soil deposit over bedrock in steep slope whereas rockslides were common in heavily jointed and open jointed rock forming steep cliff. Landslides were observed as long tail landslide and travelled long distance from top to bottom by scouring and destroying on the way. In monsoon, landslides can also trigger debris flow event by heavy continuous rain falls where water flow rate is substantially high and easily erodes remaining landslide debris along the path. Landslides triggered during main and aftershocks along valleys blocked roads, damaged houses, damaged hydro structures and dammed rivers, causing hundreds of fatalities. The total number of triggered landslides is in the few tens of thousands (GEER, 2015). The Langtang landslide was the largest and the most destructive landslide resulted from the earthquake (Fig. 3). This landslide started snow avalanche followed by debris and buried the whole Langtang Vllage killing over 350 people. Similarly, access road of hydro projects in the Trishuli River, the Bhote Koshi River and the Tamakoshi River valleys were damaged.

\section{Rock falls}

Rock falls were common in heavily jointed and open jointed rock forming cliff, whereas Boulders falls were observed in thick colluvial and alluvial soil deposits resting over bedrock in steep slope. Rock falls severely damaged access road, surface settling basin, penstock pipe and powerhouse of the Mailung, Bhotekoshi, Upper Handi Khola, Sipring, and the Baramchi Hydro Projects (Fig. 2).

\section{River damming by landslides}

River damming event creates large reservoir upstream and raise level of water along a river and consequently inundates infrastructures. Total 10 River damming events were observed in Kaligandaki River, Marsyangdi River, Trishuli River and Budigandaki River valley and no major damaged was recorded (ICIMOD, 2015 \& GEER, 2015). The most alarming landslide damming event was Baseri Landslide, estimated volume of $300,000 \mathrm{~m}^{3}$, on the left bank of the Kaligandaki River after 29 days of the mainshock burring 27 houses. Tension cracked was developed by Mw 7.8 mainshock on 25 April 2015 and widened by Mw 7.6 aftershock on 12 May 2015 and blocked the Kaligadaki River on 24 May 2015 (GEER, 2015). The lake was overtopped after 16 hours and no major damage was done by LDOF due to evacuation. Other events were dammed the rivers and draining through a small channel.

\section{Landslide dam outburst flood (LDOF)}

Sudden outburst of water from the river damming event generates flood downstream along the valley. LDOF were observed in Marsyangdi River, Kaligandaki River and Trishuli River valleys without incident. Major LDOF event in Kaligandaki valley after 16 hours river damming damaged about $2 \mathrm{~km}$ road from Beni to Jomsom and no incident in 144 MW Kaligandaki Hydro Plant located about $64 \mathrm{~km}$ downstream due to opening of all gates. In most cases river dam lakes breached partially with impounded small lake and hence no major damaged 
downstream. For instance, the Gogane Landslide in the Marsyangdi River valley with an estimated volume of 150,000 cu. m partially breached after a week of the earthquake with impounded small lake. In some cases, river damming landslides consisted of primarily permeable coarse rock fragments with very little fine and hence no water was impounded. Still there were river damming landslides in the Marsyangdi River and the Trishuli River after 2015 weak monsoon and could pose hazard in coming monsoon.

\section{Glacial Lake Outburst Flood (GLOF)}

There was high risk of GLOF due to collapse of unconsolidated moraine dam lakes and overtopping of unconsolidated moraine by large displacement waves during the earthquake. The Tsho Rolpa Glacial Lake located in the Rolwaling Valley, Gaurishanker region i.e. the upper catchment of the Tamakoshi Valley about $8 \mathrm{~km}$ from the epicentre of Mw 7.6 earthquake aftershock at Dolakha, was stand still. Luckily the lake was frozen and only minor cracks (1-3 m horizontal and $0.5 \mathrm{~m}$ vertical) were developed on the unconsolidated moraines probably due to slumping of moraine materials towards the lake (Kargel et al., 2015; USAID, 2015). There were Upper Tamakoshi Hydro Project under construction and 60MW Khimti I Project under operation downstream of the Rolwaling Valley. Similarly, the Imja Glacier Lake in the Everest region (upper catchment of the Dudhkoshi River) and the Thulagi Glacier Lake in the Manaslu region (upper catchment of the Marsyangdi River) were not breached by the earthquake. Deteriorating terminal and lateral moraines of all three lakes through the creation of massive cracks, shifted boulders, avalanche tracks, and impacts on their outlet channels were reported by USAID (2015).

\section{Liquefaction}

Liquefaction normally occurs in saturated, low density, uniformly graded sand due to strong ground shaking by an earthquake. Most of soils in the river valleys are heterogeneous well graded coarse-grained soil in fine silt and clay. These are very less susceptible to liquefaction. However, in banks and river dammed areas, liquefaction susceptible soils could be present. So far no any liquefaction events were registered in the surface structures of hydro projects. Some houses in the Kathmandu Valley were damaged by liquefaction. Liquefaction in top of the terminal moraine of the Tsho Rolpa Glacier Lake was reported by USAID (2015).

\section{OVERVIEW ON EARTHQUAKE DAMAGED HYDRO PROJECTS}

The recent Gorkha Earthquake damaged total 15 hydro projects under operation and construction hydro projects mainly by landslides and rock falls and partly by ground shaking. In hydro projects, severe damages were recorded in surface structures such as power house, settling basin, penstock pipes, and diversion weir constructed at base of steep terrains. Damages of different hydro projects were summarised in Table 1 and 2.
Brief descriptions of some of hydro projects damaged by Nepal earthquake were summarised below:

\section{Upper Bhotekoshi Hydropower Project (45 MW)}

The 45 MW Upper Bhotekoshi Project is a "run-of-theriver" project located in Sindhupalchok, north east of Kathmandu, on operation since 2001. Project's major components are $15 \mathrm{~m}$ high dam, surface settling basin, $3.3 \mathrm{~km}$ long (4 m span) headrace tunnel, $45 \mathrm{~m}$ high surge shaft, $370 \mathrm{~m}$ long (3 m dia.) surface penstock and surface powerhouse. Surface penstock pipe at one place was ruptured by rock falls and powerhouse located immediate downstream of the penstock was flooded by water coming out of the penstock and headrace tunnel (Fig. 4). At the same time landslide from the opposite bank of the powerhouse affected minor rock falls in settling basin.

\section{Mailung Project (5 MW)}

The Mailung Project (5 MW) is a "run-of-the-river" project located in Rasuwa district north of Kathmandu, Nepal. Major structures are diversion weir, surface settling basin, 1,500 $\mathrm{m}$ long headrace penstock pipe ( $1.5 \mathrm{~m}$ diameter) and surface powerhouse. Landslides and rock falls severely damaged the major structures after 9 months of operation.

The weir and intake structures were safe but concrete guide wall at downstream of weir was cracked and tilted by big boulder falls. Landslides and rock falls from the both banks deposited debris upstream of the weir and filled the intake after monsoon flood. Settling basin's middle and hill-side slope walls were mostly destroyed at middle section and deposited big boulders (Fig. 5). The settling basin was built at toe of steep colluvium deposit by cutting and still poses risk of landslide damage in heavy monsoon. More than 80 percentage of headrace penstock pipes were affected by the earthquake induced landslides and rock falls. Penstock pipe squashed and ruptured by landslide and rock falls (Fig. 5) in exposed sections located at base of rock cliff and covered by landslides in buried sections located at base of steep colluvium slope i.e. old stable landslide. A RCC beam of power house on the south side was torn down by rock fall and collapsed the wall. The auxiliary equipments placed at the turbine-generator set of right unit were also damaged. About $90 \%$ of access road was buried and damage by landslides and rock falls as result very difficult to rebuild this project.

\section{Sipring Hydropower Project (9.6 MW)}

The Sipring Hydropower Project is a "run-of-the-river" project located in Dolakha district, east of Kathmandu. Major components are diversion weir, surface settling basin, $1.5 \mathrm{~km}$ long headrace tunnel (2.5 m span), forebay, $786 \mathrm{~m}$ long surface penstock and surface powerhouse.

Penstock pipe and surface powerhouse constructed along the steep slope and at base of the steep slope on the left bank of the Tamakoshi River respectively. Forebay that was completely destroyed by rock falls was constructed close to a dry gully 
Table 1: Records of damaged hydro-projects on operation by the Nepal Earthquake 2015

\begin{tabular}{|c|c|c|c|}
\hline S.N. & Name of Projects & Structures damaged & Induced Hazards \\
\hline 1 & $\begin{array}{l}\text { Upper Bhotekoshi (45 MW), } \\
\text { Sindhupalchok }\end{array}$ & $\begin{array}{l}\text { Penstock pipe ruptured by rock falls and powerhouse } \\
\text { flooded by water from headrace tunnel, minor rock falls } \\
\text { in settling basin. }\end{array}$ & Rock falls, landslides, \\
\hline 2 & Mailung (5 MW), Rasuwa & $\begin{array}{l}\text { Intake covered by landslides debris, settling basins } \\
\text { damaged by rock falls, penstock pipe ruptured and } \\
\text { squeezed in several places by rock falls, one } \\
\text { powerhouse tie beam damaged hit by big boulder, } 2 \\
\text { transmission line towers damaged, } 90 \% \text { access road } \\
\text { destroyed by landslides and rock falls. }\end{array}$ & Landslides, rock falls \\
\hline 3 & Sipring (9.6 MW), Dolakha & $\begin{array}{l}\text { Forebay destroyed by rock falls; } 20 \% \text { penstock pipe } \\
\text { ruptured and punched by rock falls; and powerhouse } \\
\text { walls and roof punched by rock falls. }\end{array}$ & Rock falls, landslides \\
\hline 4 & $\begin{array}{l}\text { Bhairabkunda } \\
\text { Sindhipalchok }\end{array}$ & $\begin{array}{l}\text { Weir buried by landslide, shotcrete cracked in few } \\
\text { places of tunnel, penstock pipe ruptured by landslide, } \\
\text { powerhouse wall punched by rock falls and switchyard } \\
\text { damaged landslides. }\end{array}$ & Landslides, rock falls \\
\hline 5 & $\begin{array}{l}\text { Baramchi (4.2 MW }) \text {, } \\
\text { Sindhupalchok }\end{array}$ & $\begin{array}{l}\text { Penstock pipe ruptured at several places by landslides } \\
\text { and rock falls. }\end{array}$ & $\begin{array}{l}\text { Rock falls and } \\
\text { landslides }\end{array}$ \\
\hline 6 & $\begin{array}{l}\text { Upper Hadi Khola }(0.99 \\
\text { MW), Sindhupalchok }\end{array}$ & $\begin{array}{l}\text { Penstock pipe ruptured in several places by rock falls, } \\
\text { powerhouse walls fell off by shaking, switchyard } \\
\text { damaged by rock falls. }\end{array}$ & $\begin{array}{l}\text { Rock falls, landslides } \\
\text { and ground shaking }\end{array}$ \\
\hline 7 & $\begin{array}{l}\text { Sunkoshi Sanima (2 MW), } \\
\text { Sindhupalchok }\end{array}$ & Powerhouse walls collapsed and columns cracked. & Ground shaking \\
\hline 8 & $\begin{array}{l}\text { Sunkoshi (10 MW }) \\
\text { Sindhupalchok }\end{array}$ & Canal cracked and minor settlement in power house. & Ground shaking \\
\hline 9 & $\begin{array}{l}\text { Kulekhani Storage Project } \\
\text { (94 MW), Makwanpur }\end{array}$ & $\begin{array}{l}\text { Cracks in } 100 \mathrm{~m} \text { length of the Rock filled dam crest } \\
\text { ( } 114 \mathrm{~m} \text { high and } 406 \mathrm{~m} \text { long) with } 10 \mathrm{~cm} \text { settlement. } \\
\text { Reduced } 3 \mathrm{~m} \text { water level for operation. }\end{array}$ & Ground shaking \\
\hline 10 & Ankhu I (8.4 MW), Dhading & $\begin{array}{l}\text { Powerhouse and sub-station damaged by landslide, } 11 \\
\text { TL poles damaged. }\end{array}$ & Landslides \\
\hline
\end{tabular}

Table 2: Records of damaged hydro-projects under construction by the Nepal Earthquake 2015

\begin{tabular}{|c|c|c|c|}
\hline S.N. & Name of Projects & Damaged structures & Induced Hazards \\
\hline 1 & $\begin{array}{l}\text { Upper Chakhu (40MW), } \\
\text { Sindhupalchok }\end{array}$ & $\begin{array}{l}\text { Penstock pipe, powerhouse, settling basin, and access road } \\
\text { damaged by rock falls. }\end{array}$ & Landslides, rock falls \\
\hline 2 & $\begin{array}{l}\text { Rasuwagadhi } \\
\text { Rasuwa }\end{array}$ & $\begin{array}{l}\text { Coffer dam and access road damaged by rock landslides } \\
\text { and rock falls, rock falls in tunnel. }\end{array}$ & Landslides, rock falls \\
\hline 3 & $\begin{array}{l}\text { Upper Trishuli 3A (60MW), } \\
\text { Rasuwa }\end{array}$ & $\begin{array}{l}90 \% \text { Access road damaged by rock falls and landslides; } \\
\text { minor rock falls hit intake and guide walls. }\end{array}$ & Landslides, rock falls \\
\hline 4 & $\begin{array}{l}\text { Upper Tamakoshi (456MW), } \\
\text { Dolakha }\end{array}$ & $\begin{array}{l}17 \mathrm{~cm} \text { Dam settlement by ground shaking; minor rock falls } \\
\text { in dam walls and access road damaged by landslides and } \\
\text { rock falls. }\end{array}$ & $\begin{array}{l}\text { Rock falls, landslides, } \\
\text { ground shaking }\end{array}$ \\
\hline
\end{tabular}

(Fig. 6). Similarly, $165 \mathrm{~m}$ length (21\%) of surface penstock pipe w ere ruptured and squeezed by rock falls. Rock falls made severa 1 holes in wall on slope side and roof of powerhouse like bullet s.

\section{bkunda Hydropower Project (3 MW)}

airabkunda Hydropower Project is a "run-of-the-river" project located in the Sindhupalchok District near China boarder north 

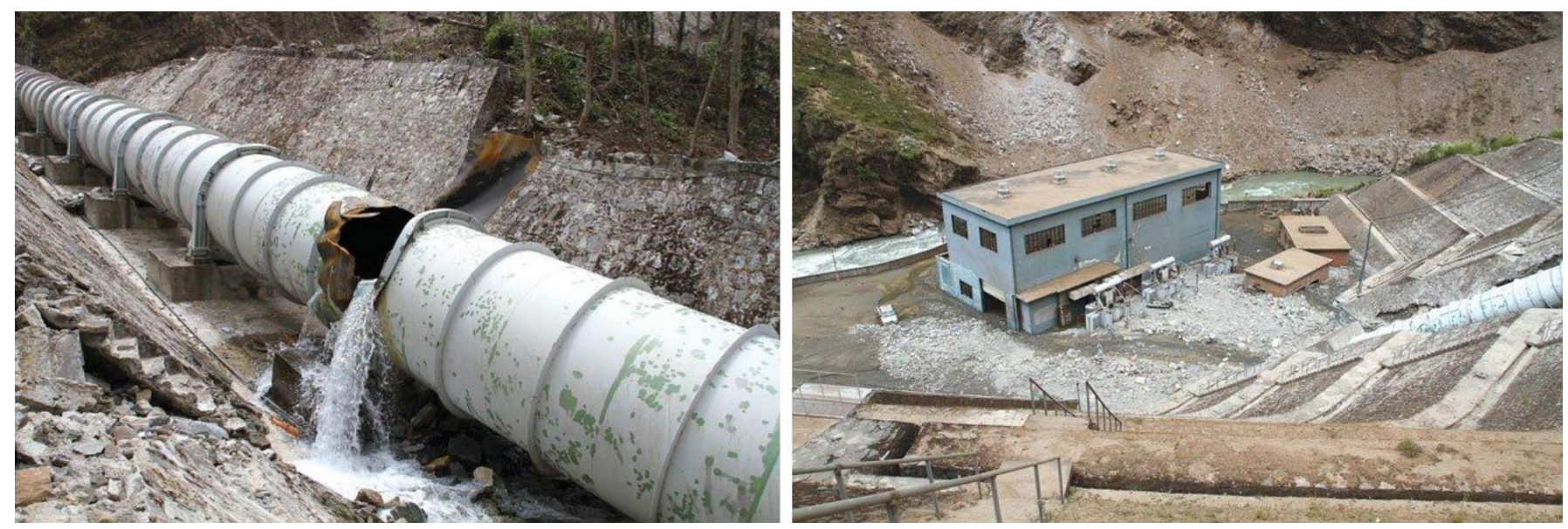

Fig. 4: Ruptured penstock pipe by rock falls and flooded powerhouse immediately downstream (Photo: Kantipur Daily)
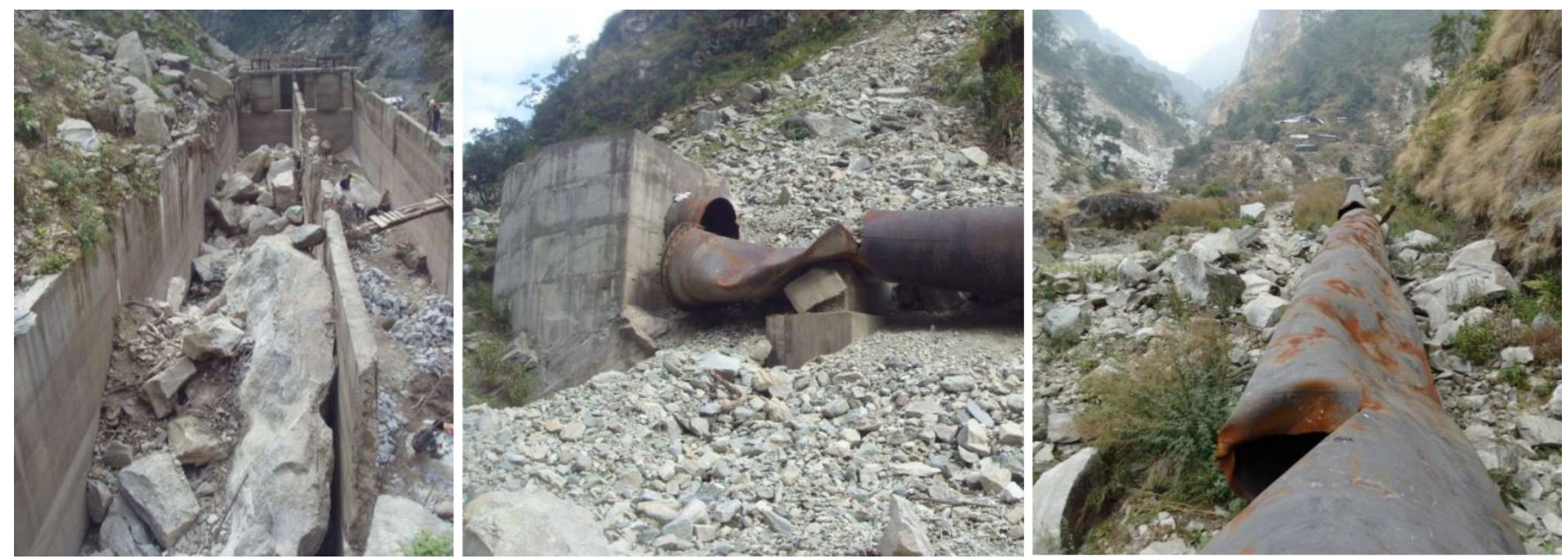

Fig. 5: Damaged settling basin and ruptured penstock pipes
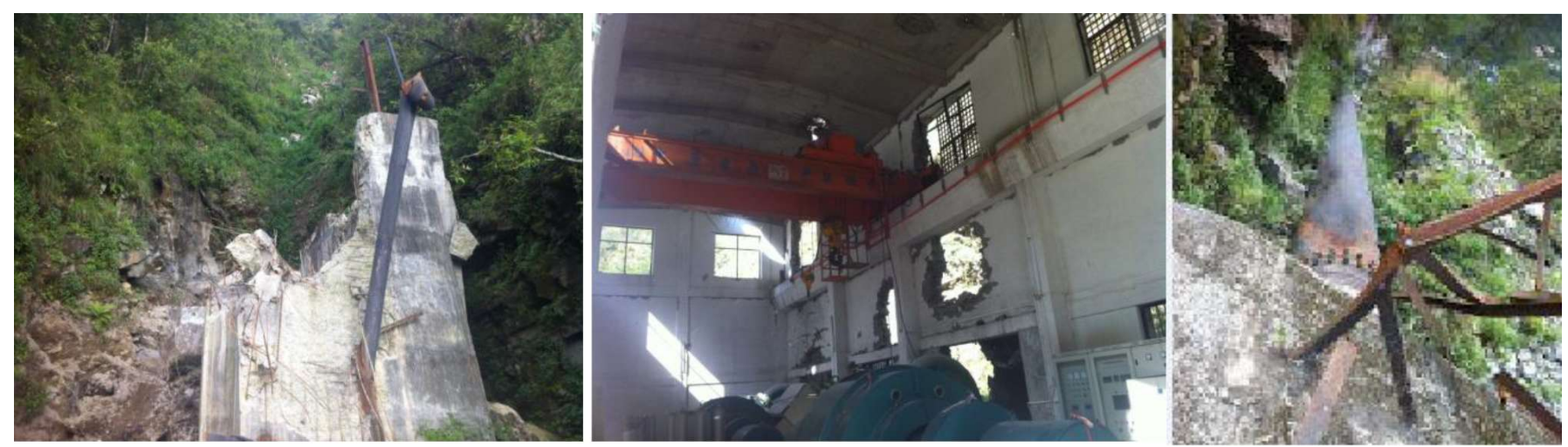

Fig. 6: Destroyed Forebay, punched powerhouse walls/roof and squeezed penstock pipe (Photo: Soyuz Gautam)

east of Kathmandu, Nepal. Major components are diversion weir, surface settling basin, $695 \mathrm{~m}$ long headrace tunnel $(2.2 \mathrm{~m}$ wide and $2.5 \mathrm{~m}$ high), surge shaft, $250 \mathrm{~m}$ long surface penstock and surface powerhouse. Diversion weir built downstream of old landslide was completely buried by landslide (Fig. 7).
Shotcrete in the headrace tunnel was cracked in few places. Penstock pipe built along steep hill was also ruptured at one place by the landslide (Fig. 7) and punched at few places by rock falls. Powerhouse located at the base of hill was punched by rock falls whereas the switchyard was damaged by landslides. 

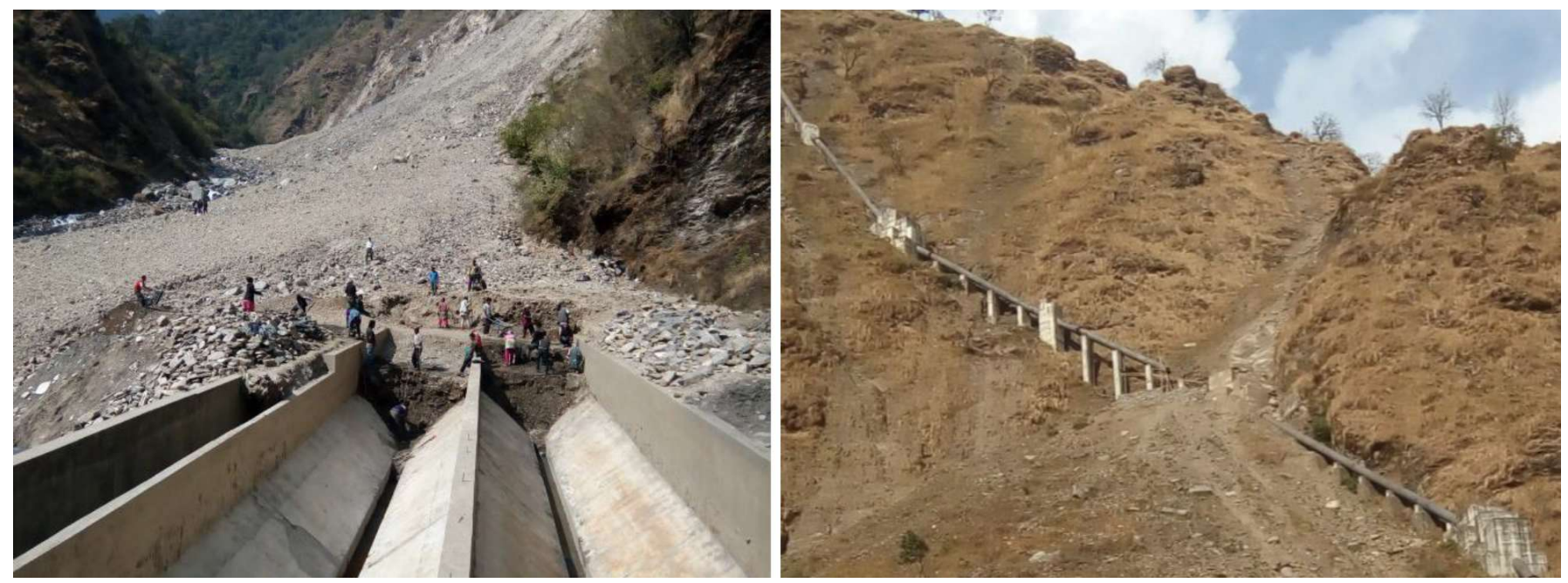

Fig. 7: Buried weir, re-excavated settling basins (Photo: Bishwo Vijaya Shrestha) and ruptured penstock pipe

\section{LESSONS LEARNED FOR DESIGN CONSIDERATIONS}

In hydro projects there is a practice of considering seismic load in design of structures but the effects of earthquake induced hazards were not foreseen. This devastating earthquake gave good lessons for design considerations of hydro projects in coming days. Earthquake risks due to strong ground shaking and earthquake induced hazards are the major lessons learned for design considerations. Seismic design code which estimates value of Peak Ground Acceleration (PGA) to address risk of strong ground shaking. Conversely, there are no strict guidelines and design considerations to address and foresee risks of earthquake induced hazards. Therefore, some useful steps as guidelines to minimise earthquake induced hazards of hydro projects are: (a) Seismic design code and probabilistic seismic hazard assessment, (b) Potential earthquake induced hazards and risks assessment, and (c) Design considerations

\section{Seismic design code and probabilistic seismic hazard assessment}

Seismic design code and Probabilistic seismic hazard assessment will address risk of strong ground shaking by estimating value of Peak Ground Acceleration (PGA) in Operation Basis Earthquake (OBE) and Maximum Design Earthquake (MDE) for design of hydro structures. Generally used Seismic codes are Nepal Building Code (NBC, 1005:1994) and India Standards: Criteria for Earthquake Resistance Design. In practice PGA from codes are normally applied for small hydro projects whereas Probabilistic Seismic hazard analysis is normally carried out only for big projects. However, in the probabilistic analysis sources and fault model are important but usually in the Himalaya, major earthquakes generated by rupture along decollement blind thrust known as the Main Himalaya
Thrust (GEER, 2015) at about 10 to $15 \mathrm{~km}$ depths. Epicentres of historical big and great earthquakes were located surrounding area of the MCT at surface. Therefore, there is a challenge of predicting active blind thrust fault which could generate big earthquake. Most of surface power houses and structurally well built resident houses were not structurally damaged by strong ground shaking in the recent earthquake which indicated that PGA considered for design seems satisfactory (GEER, 2015). Conversely, measured PGA of $0.16 \mathrm{~g}$ in Kantipath, Kathmandu station and in other seismological satiations were surprisingly lower (GEER, 2015) than expected. Therefore, modification of codes and standards and re-estimation of PGA with different zones is essential based on this recent earthquake information.

\section{Potential earthquake induced hazards and risks assessment}

Landslides including rock falls were found posing major risks in the recent Nepal earthquake occurred in April end of winter season but case could be different if earthquake had occurred in wet season which means debris flow, river damming, LDOF and GLOF could also pose risk. Therefore, identification of potential hazards and risk assessment are important during site selection and design studies to minimise risks. Essential studies for potential hazards and risk assessment are: (a) reconnaissance study of critical landslides, (b) mass wasting study and hazard mapping, (c) detailed landslides and rock falls mapping and analysis, (d) dam break analysis and maximum flood level of GLOF, (e) liquefaction hazard, and (f) risk assessment of structures.

Generally, structures at the base of rock cliff and steep slope, close to river banks, narrow ridges, loose soil and jointed/weathered rock on top of steep slope, loose thick soil in steep terrains, old landslides and in loose and saturated soil 
are the most vulnerable. Therefore, risk assessments of major hydro structures in such sites are more critical. Additionally, liquefaction risk assessment for major surface structures is also important.

\section{Reconnaissance study of critical landslides}

Reconnaissance study of critical landslides upstream and downstream of catchment has to carry out to identify risk of a river damming, possibility of inundation of structures and LDOF. In addition, study of historical old landslides is important to predict risk in the valley. Google earth and other satellite images can be used for the study. Further detailed study and risk assessment are necessary to carry out only if there are critical landslides present.

\section{Mass wasting study and hazard mapping}

Mass wasting study and hazard mapping is very useful to predict landslides, rock falls and river damming. First preparation of engineering geological map (showing landslides, rock falls, run out areas, damming areas, soil, bedrock outcrop, hanging river terrace, shear/weak zones, faults etc.) covering minimum $2 \mathrm{~km}$ upstream and downstream of dam and tail water boundary is compulsory. Engineering geological map facilitates to identify and quantify risky mass wasting areas. Hazard map will help to investigate possible hazard of landslides, rock falls and river damming by classifying as high, medium and low hazards. Finally, detailed analysis and risk assessment will be concentrated in high hazard areas on the basis of engineering geological map and hazard map.

\section{Detailed landslides and rock falls analysis}

Detailed landslides including rock falls analysis of high hazard areas are to be carried out for major structures. Site investigations, in situ test and laboratory tests are necessary to collect ground water table, rock and soil properties for analysis. Detailed analysis of landslides and rock falls can be done by different software available in the market.

\section{Dam break analysis of GLOF}

Maximum flood level can be estimated by dam break analysis of GLOF using dam breach software and hence safe level can be finalised for design of major structures with protection design. For example, maximum flood level of the Tsho Rolpa GLOF in the Tamakoshi Valley including Powerhouse site of the Khimti I Hydropower Project at the Kirne area was estimated by dam break analysis and safe level was considered in design.

\section{Liquefaction hazard}

Liquefaction hazard of major hydropower structures such as dam and powerhouse can be estimated by in situ tests like SPT, density, ground water level, shear wave velocity etc. Additionally, the liquefaction hazard maps of Pokhara and
Kathmandu, that were produced by Department of Mines and Geology, could be useful for reference.

\section{Risk assessment of structures}

Based on the above studies, hazards and evaluation of all potential different risks of every structure of hydro projects should be listed out. Besides, level of risks and possible design considerations should be evaluated to mitigate risks.

\section{Design considerations}

Identification of earthquake induced hazards and risks to hydro structures are foremost important for design considerations. General design considerations to optimise the risks are

(a) Avoidance of risky areas if possible

(b) Stabilization of potential hazards areas if possible

(c) Designing protective structures: retaining structures (gabions), anchoring and shotcrete support, heavy concrete protection or bypass structures, buried structures, nets, steel mesh in rock falls, and automatic valve for surface penstock

(d) Underground alternative options in high risk areas

(e) Safe level from flood and protections like automatic gates, flood control structures, early warning system.

\section{Design connsiderations for landslides and rock falls}

Surface structures and portals at steep terrain, base of steep slopes, old landslides and rock cliff are high risk for rock falls and landslides. Hence in such terrains above listed general design considerations shall be considered. Similarly, surface penstock pipe, canal, and forebay in steep slopes of mountainous terrain are high risks of rock falls, landslides, settlement and erosion. To minimise risk the following design shall be considered:

(a) Avoid steep colluvium, creeping old landslide, gully and flow path if possible

(b) Stable ground preferable along bedrock and ridge

(c) Buried in rock falls, gullies crossings and landslides risks sections

(d) Protection structures: retaining structures, gabions, concrete structures, anchoring, shotcrete, catch nets etc.

(e) Underground in high risk sections

(f) Automatic valve at starting of surface penstock

\section{Design considerations for liquefactions}

Although majority of hydro projects sites consist of less liquefaction risk boulders mixed heterogeneous soil but still risk in some sites due to thick silt and sand deposits by river damming event in past. Therefore, site investigations are 
necessary to assess liquefaction risk. Compaction, grouting, loading, replacement, drains and piling are treatments methods for liquefaction whichever will be viable can be considered during design phase.

\section{Design considerations for $L D O F$ and GLOF}

River damming and LDOF events are difficult to predict which require proper study, investigation, analysis and monitoring. Maximum flood level of GLOF can be predicted and structures can be located at safe level. Normally safe level is considered in design for GLOF risk. Other protective measures like flood control structures, automatic gates, early warning system etc. are useful design.

\section{CONCLUSIONS}

1. The Mw 7.8 Gorkha Earthquake on 25 April 2015 and Mw 7.3 aftershocks on 12 May severely damaged mainly surface structures of hydro projects, access roads, clay mortar stone masonry houses and structurally weak concrete houses.

2. Among earthquake-induced hazards landslides, rock falls and strong ground shaking were mainly responsible for major damaged.

3. A total of 15 hydro projects in operations and under construction were affected by the earthquake and more damages were recorded in surface structures constructed at base of steep slopes.

4. Underground structures were found safer and only minor cracking of sprayed concrete at corners and protruded edges were observed.

5. In hydro projects there is a practice of considering seismic load in design of structures but the earthquake induced hazards were not foreseen.

6. There are no strict guidelines and design considerations to address and foresee risks of earthquake induced hazards.

7. To minimise earthquake induced hazards of hydro projects Seismic hazard assessment; earthquake induced hazards and risks assessment; and protective designs are considered as guidelines for design considerations.

\section{ACKNOWLEDGEMENT}

I would like to acknowledge Soyuz Gautam, Bishwovijaya Shrestha and Kantipur media for providing me photographs of damaged structures of different hydro projects.

\section{REFERENCES}

Aydan, O. and Ulusay, R., 2015, A quick report on the 2015 Gorkha (Nepal) earthquake and its geo-engineering aspects. Unpublished report, 26p.
Ader, T., Avouac, J P., Liu-Zeng, J., Caen, H L., Bollinger, L., Galetzka, J., Genrich, J., Thomas, J., Chanard, K., Sapkota, SM., Rajaure, S., Shrestha, P., Ding, L., and Flouzat, M., 2012, Convergence rate across the Nepal Himalaya and interseismic coupling on the Main Himalayan Thrust: Implications for seismic hazard, J. Geophys. Res., v. 117, B04403, pp. 1-16. doi:10.1029/2011JB009071,

Bhattarai, M., Adhikari, L. B., Gautam, U. P., Laurendeau, A., Labonne, C., Hoste-Colomer, R., Sebe, O., and Hernandez, B., 2015, Overview of the Large 25 April 2015 Gorkha, Nepal, Earthquake from Accelerometric Perspectives. Seismological Research Letter, v. 86, no. 6, pp. 1540-1548.

GEER, 2015, Geotechnical Field Reconnaissance: Gorkha (Nepal) earthquake of April 252015 and related shaking sequence. GEER Association Report No. GEER-040, Version 1, July 29 2015, 250p.

ICIMOD, 2015, Geohazards aftermath of the 25 April 2015 earthquake, A rapid analysis prepared for the Government of Nepal. Report, pp.1-16.

IRIS, 2015, Magnitude 7.8 Nepal, Saturday April 25, 2015, 6:11:26 UTC, Document available in http://www.iris.edu

Kargel, JS., Leonard, G.J., Shugar, D.H., Haritashya, U.K., Bevington, A., Fielding, E.J., Fujita, K., Geertsema, M., Miles, E.S., Steiner, J., Anderson, E., Bajracharya, S, Bawden, G.W., Breashears, D.F., Byer, S.A., Collins, B., Dhital, M.R., Donnellan, Evans, A., T.L., Geai, M.L., Glaasscoe, M.T., Green, D., Gurung, D.R., Heijenk, R., Hilborn, A., Hudnut, K., Huyck, C., Immerzeel, W.W., Liming, J., Jibson, R., Kääb, A., Khanal, N.R., Kirschbaum, D., Kraaijenbrink, P.D., Lamsal, D., Shiyin, L., Mingyang, L., McKinney, D., Nahirnick, N.K., Zhuotong, N., Ojha, S., Olsenholler, J., Paainter, T.H., Pleasants, M., Pratima, K.C., Yuan, Q.I., Raup, B.H., Regmi, D., Rounce, D.R., Sakai, A., Donghui, S., Shea, J.M., Shreshtha, A.B., Shukla, A., Stumm, D., Kooij, M., Voss, K., Xin, W., Weihs, B., Wolfe, D., Lizong, W., Xiaojun, Y., Yoder, M.R., and Young, N., 2015, Geomorphic and Geologic Controls of Geohazards induced by Nepal's 2015 Gorkha Earthquake. Science Express, v. 351, pp. 1-9.

Takai, N., Shingefuji, M., Rajaure, S., Bijukchhen, S., Ichiyanagi, M., Dhital, M. R., and Sastani, T., 2016, Strong ground motion in the Kathmandu Valley during the 2015 Gorkha, Nepal, Earthquake. Planet and Space, v. 68(10), pp.1-8.

USAID, 2015, Post-Earthquake assessment: Imja, Tshorolpa and Thulagi Glacier lakes in Nepal, Technical Report, $65 \mathrm{p}$.

USGS, 2015, The April-May Nepal earthquake sequence, www//earthquake.usgs.gov/learn/topics/Nepal_slides.pdf. 
